\title{
Genetic relationships among suspected contact zone populations of Helix aspersa (Gastropoda: Pulmonata) in Algeria
}

\author{
ANNIE GUILLER* ${ }^{*}$, MARIE-AGNÈS COUTELLEC-VRETO $\ddagger$ \& LUC MADEC $\ddagger$ \\ †Laboratoire de Parasitologie Pharmaceutique (CNRS URA 1853), Université de Rennes I, Avenue du Pr. Léon \\ Bernard, 35043 Rennes and $\ddagger$ Laboratoire de Zoologie et d'Ecophysiologie (INRA-CNRS URA 1853), Université de \\ Rennes I, Avenue du General Leclerc, 35042 Rennes, France.
}

\begin{abstract}
In Maghreb, the land snail Helix aspersa consists of two anatomically and biochemically divergent groups of populations between which the separation occurs roughly to the east of the Lesser Kabylia. To document the patterns of migration across the suspected contact zone between these two geographical entities, we have analysed changes in allele frequencies at 13 polymorphic allozyme loci in five intermediate Algerian populations ranging from Azeffoun (Great Kabylia) to El Hedaick (Skikda), thus including three western and two eastern colonies. Multivariate analyses and exact tests for population differentiation were used to show the genetic divergence between samples; deviations from panmixia were calculated to account for the effect of migration. Whereas some loci showed abrupt changes in allelic composition across the hybrid zone, some others were introgressed, especially into eastern populations in the central colony of Djemila. It is tempting to ascribe this allelic distribution to gene exchanges between populations on the east and west. However, the large number of private alleles found in adjoining populations apparently does not support this explanation, although such an increase in rare alleles has been observed in other hybrid zone surveys. In addition, it may be that this discrepancy between the patterns of common and private allele variation may result from the time since contact occurred. Whatever the explanation of this finding, the genetic structure in Djemila, and particularly the large linkage disequilibria observed, indicates population mixing. Although not ruling out the possibilities of tectonic events and of human transport, the most likely hypothesis for contacts between eastern and western populations are that these result from climatic phenomena during the Quaternary.
\end{abstract}

Keywords: allozymes, contact zone, genetic structure, Helix aspersa, Maghreb, postglacial expansion.

\section{Introduction}

Hybrid zones have been described in a great variety of organisms but, up to now, most of these have involved contact between closely related species rather than intraspecific taxa (Barton \& Hewitt, 1985). A hybrid zone, as defined by Harrison (1993), 'occurs when genetically distinct groups of individuals meet and mate, resulting in at least some offspring of mixed ancestry'. In terrestrial molluscs, reports on natural hybridization between distinct populations have mainly concerned three wellknown genera, namely Cerion (Gould \& Woodruff, 1978; Woodruff \& Gould, 1987; Woodruff, 1989),

\footnotetext{
${ }^{*}$ Correspondence.
}

Partula (Clarke, 1968; Johnson et al., 1993) and Cepaea (Cain \& Currey, 1963; Johnson, 1976). The last two taxa were especially interesting because of specific patterns of morphological and biochemical differentiation known as 'area effects'. Indeed, this population structuring, representing 'coadapted constellations of alleles' (White, 1978, in Jones et al., 1980), resembles the geographical pattern of variation described in Helix aspersa. In this land snail, allozyme variation among allopatric populations located throughout the species range has revealed the existence of two main geographically differentiated groups (Nei's genetic distance $D=0.18$ ): an eastern one seen in samples from East Maghreb (from East Kabylia to Tunisia) and Epirus (Greece) and a western block including populations from 
West Algeria and Europe (Guiller et al., 1994). Moreover, this biochemical differentiation is mirrored by the pattern of biometrical variation, especially in the length of one genital organ, the diverticulum of bursa copulatrix (Madec \& Guiller, 1994). These patterns of concordant geographical variation of both biochemical and anatomical characters have drawn our attention to the relationships among populations located between the western and eastern Algerian groups, such populations usually being interpreted as evidence for a secondary contact between formerly isolated populations that diverged from a common ancestor. Preliminary results indicated the existence of a contact zone between peripheral populations of the two regions. Based on the clines in allele frequencies, this overlap area, $200 \mathrm{~km}$ wide, lies somewhere between the Great Kabylian colony (Azeffoun) devoid of eastern diagnostic alleles, and an eastern one close to Skikda (El Hedaick).

The present investigation describes the spatial distribution of allozymes in five samples collected at the boundary between eastern and western populations in Algeria. The main objective is to investigate the existence of this hypothetical contact zone by combining data on the degree of geographical population partitioning and the genetic structure. In practice, we may detect the effect of migration (distant past and more recent gene flew) among populations through deviations from panmixia, i.e. heterozygote deficiencies and linkage disequilibria. The Wahlund effect owing to population mixing with one or two genes is actually another possible source of departures from Hardy-Weinberg equilibrium (Nei \& Li, 1973).

\section{Materials and methods}

\section{Study area and sample characteristics}

Thirty-two samples of $H$. aspersa from Maghreb were collected along an east-west transect between Bizerte and Rabat, with five originating from Tunisia, 24 from Algeria and three from Morocco (Fig. 1). Each sampling area, described in detail in our previous paper (Guiller et al., 1994), was no larger than $5000 \mathrm{~m}^{2}$ or no longer than $70 \mathrm{~m}$ (Madec, 1989) and sample size varied between 15 and 50 individuals. Apart from one sample (the Moroccan population close to Rabat, $\mathbf{M}_{1}$ ) which included 'giant' snails which may represent the subspecies $H$. a. maxima (maximum diameter $=45.9 \mathrm{~mm}$; height $=42.9 \mathrm{~mm}$ ), all populations contained only individuals exhibiting conchological measurements of the H. a. major type (diameter $36.7 \mathrm{~mm}$; height $33.7 \mathrm{~mm}$ ) (Taylor, 1913). Despite this apparent homogeneity, the allozyme and genital variation defined two distinct geographical forms with, respectively, the following ranges (Guiller et al., 1994; Madec \& Guiller, 1994).

1 In Algeria, the western group runs from Cap Lares $\left(A_{1}\right.$, near Cherchell) to Djemila $\left(A_{14}\right.$, Lesser Kabylia). Snails from this region have a middle-sized diverticulum of their bursa copulatrix (diverticulum/ diameter ratio $=1.78$ ).

2 The eastern block lies between the station of El Ancer $\left(A_{15}\right.$, Lesser Kabylia) and Bizerte $\left(T_{5}\right)$. Individuals here have a short diverticulum (diverticulum/ diameter ratio $=1.16$ ). Within this group, both western colonies $\mathrm{A}_{15}$ and $\mathrm{A}_{16}$ differ by having a longer diverticulum and a gene pool quite different from the remaining populations (average Nei's genetic distance $D=0.15$ whereas $D=0.09$ between the other populations).

The analysis of populations between these two contiguously distributed regions may provide information clarifying the processes of differentiation, and so the variation in allelic frequencies was measured in several intermediate populations (Guiller et al., 1994). Among the seven colonies considered $\left(\mathrm{A}_{10}\right.$ to $A_{16}$ ), only those located between Azeffoun $\left(A_{12}\right)$ and El Hedaick $\left(\mathrm{A}_{16}\right)$ showed a clinal pattern of allozymic differences between the two groups. These five samples are those considered here.

\section{Electrophoresis}

Electrophoresis was performed as previously described (Guiller et al., 1994). Seventeen loci were scored for each individual in all samples. Among these, 13 were polymorphic (Lap-1, Lap-2, Got-1, Mdh-1, Me-2, Pgm-1, Pgm-2, Mpi-1, Pgi-2, Sod-1, 6 Pgd-2, Idh-1, Est-3, Est-6), the remaining ones being Eno-1, Eno-2 and $\alpha G p d-2$. Several diagnostic and alternative (most common) alleles differ between the two geographical groups. However, the mean frequencies of the diagnostic alleles were too low to produce marked differences between east and west; only the latter generated clinal variation because they are fixed in geographically extreme populations of both regions (Guiller et al., 1994).

\section{Data analysis}

In order to distinguish the markers responsible for genetic divergence at both individual and population levels, we analysed the electrophoretic data using correspondence analysis (CA) of either an incom- 


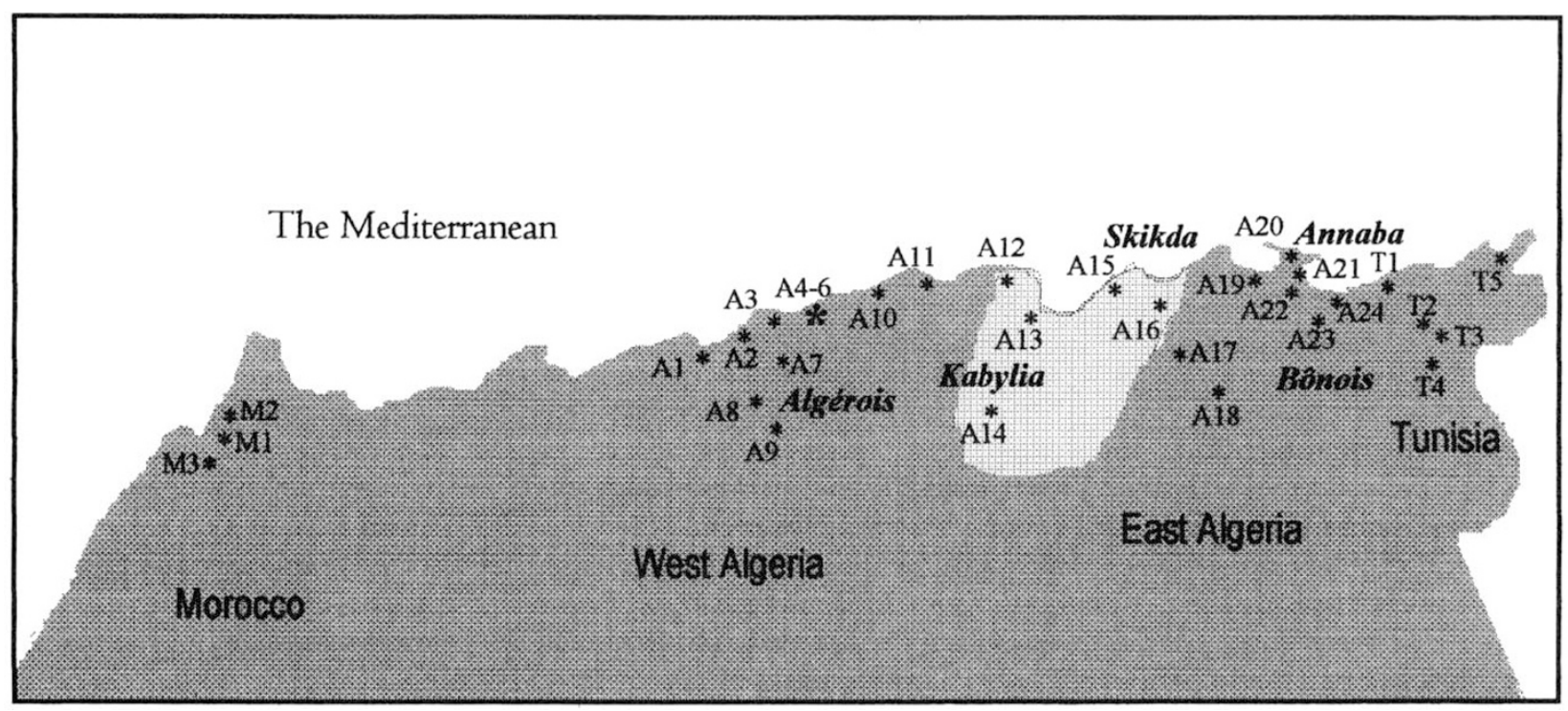

Fig. 1 Collecting sites for Maghreb populations of Helix aspersa. The stippled area indicates the suspected contact zone which extends between $A_{12}$ (Azeffoun) and $A_{16}$ (El Hedaick).

plete disjunctive table (multiple contingency table) for individuals $\times$ alleles or a contingency table for samples $\times$ alleles (Benzecri, 1973; Escofier \& Pagès, 1990). To define the appropriate partitioning of the data set, each analysis was combined with a hierarchical clustering analysis. The criterion used for aggregation was based on the maximization of the global inertia so that at each step the intraclass variance of the partition obtained was minimized. The detailed steps of these methods, particularly the coding of the crude electrophoretic data, are given by She et al. (1987). Multivariate analyses, performed with the software package ADDAD (1992) (Association pour le Développement et la Diffusion de l'Analyse des Données), were augmented with exact tests for population differentiation (see below).

Genetic variability measures (allele frequencies and heterozygosity estimates) were calculated using BIOSYS-1, release 1.7 (Swofford \& Selander, 1989). The genetic structure within and between populations was analysed with the help of two software packages. The DIPLOID program, which performs Weir \& Cockerham's (1984) modification of Wright's (1965) $F$-statistics, breaks down the variability into three hierarchical levels - individual, subpopulation and population - in order to assess the effects of nonrandom mating within subpopulations $\left(F_{\mathrm{IS}}\right)$ and the effects of population subdivision $\left(F_{\mathrm{ST}}\right)$. The fit of the data to Hardy-Weinberg expectations and genotypic linkage disequilibria between pairs of loci were analysed with GENEPOP, version 1.0
(Raymond \& Rousset, 1994). Estimation of the Hardy-Weinberg exact probability was calculated for each locus in each sample. For loci with fewer than four alleles, a Fisher exact test was performed as described by Louis \& Dempster (1987). With more than four alleles, an unbiased estimation of the exact probability was performed using the algorithm established by Guo \& Thompson (1992) (Raymond \& Rousset, 1995a; Rousset \& Reymond, 1995). To test the statistical independence between two loci, contingency tables were created for all pairs of loci in each population (the number of possible tables for $n$ loci and $p$ populations being $p n(n-1) / 2)$. Using methods based on Markov processes and two-way tables, the GENEPOP program also provided information on statistical population differentiation. The principle was to test, from a contingency table 'populations $\times$ alleles' created for each locus, the independence between the various populations (all together and in pairs) (Raymond \& Rousset, 1995b). GENEPOP then provided the estimate of the probability of error when the null hypothesis was rejected (i.e. no allelic differentiation). Though other possible multiple tests like the Bonferroni could have been performed (Rice, 1989), a Fisher test was used to combine information over loci and over populations. In order to quantify the effect of migration on the genetic divergence among these populations along a linear transect, gene flow was also estimated between each pair of demes. The method used here studied private alleles found in 
(a)

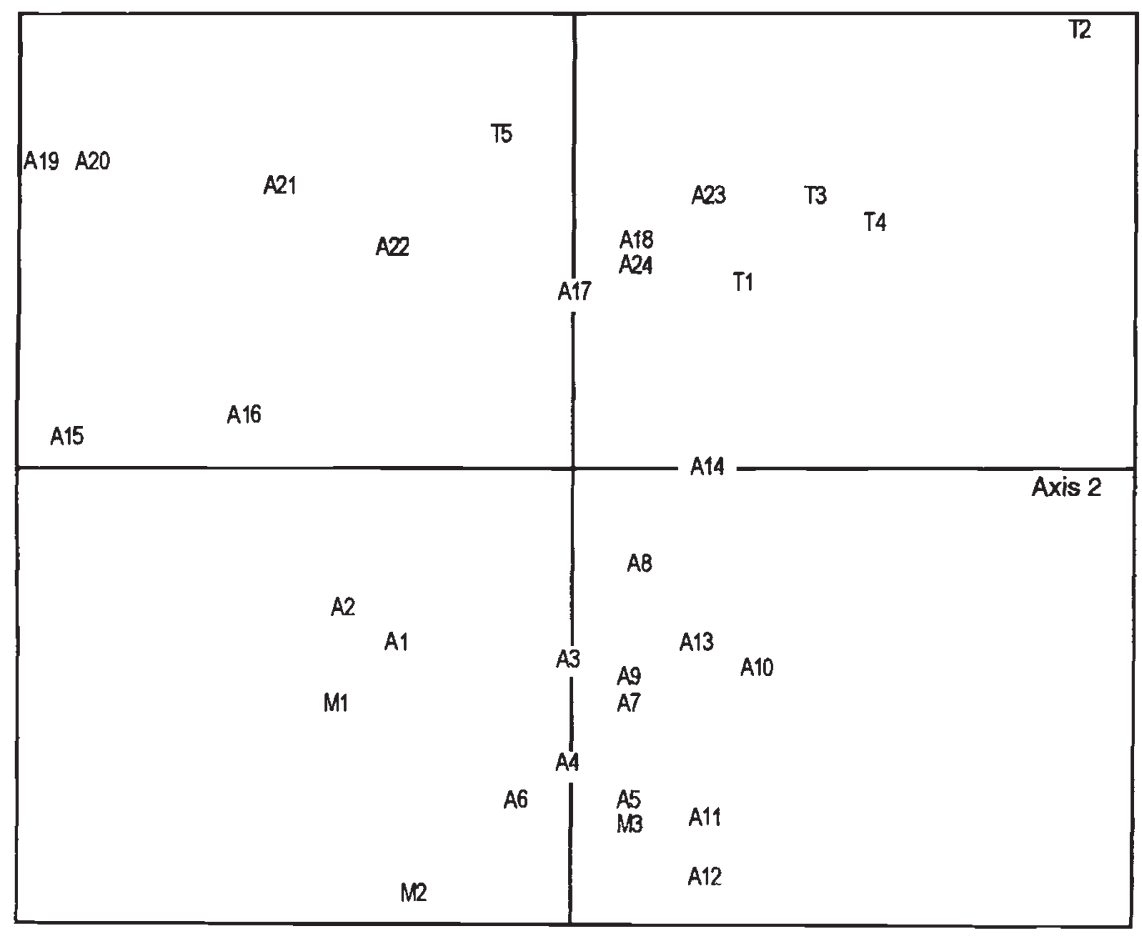

(b)

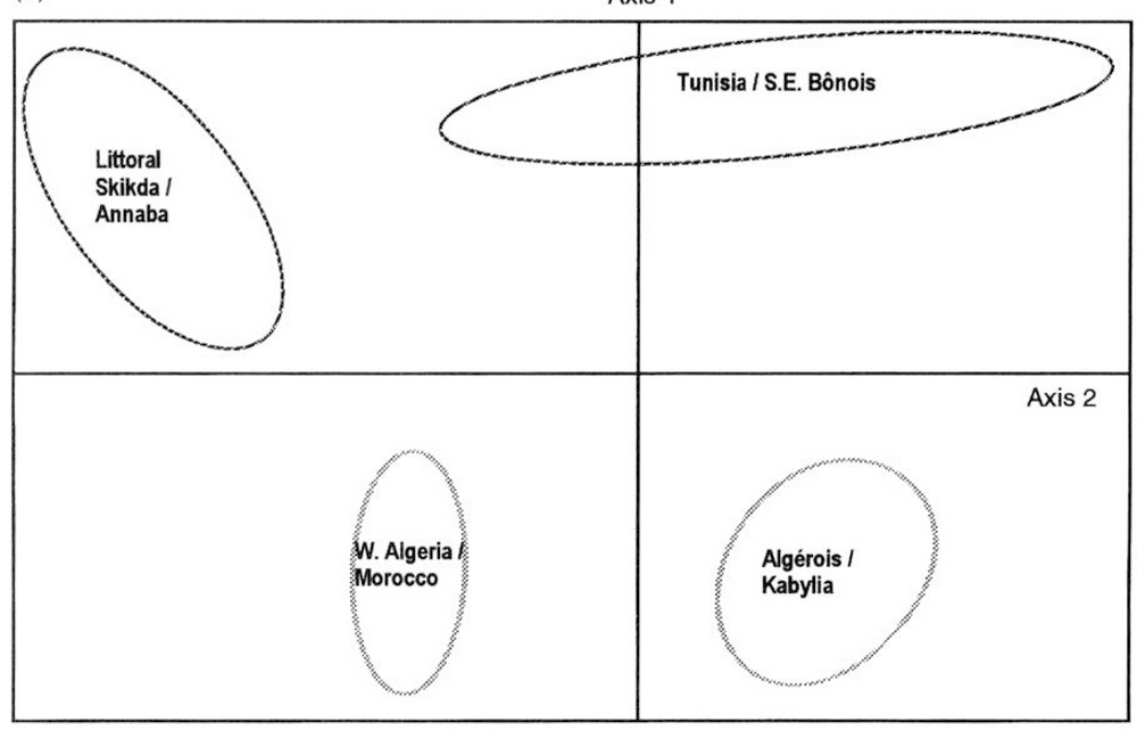

Fig. 2 Principal plane of the correspondence analysis based on 32 Maghreb populations of Helix aspersa described by 35 alleles. (a) Projection of populations; (b) four major classes defined by the hierarchical clustering analysis. populations (Slatkin, 1985). It provided four estimates of gene flow $(\mathrm{Nm})$, three using the regression lines corresponding to three different sample sizes ( $N=10, N=25, N=50$ ), one (here retained) being an estimate corrected for sample size (Barton \& Slatkin, 1986).

\section{Results}

Genetic divergence between populations

Before analysing the five suspected contact zone populations, the differentiation of all the Maghreb samples was first investigated by applying a corre-

(c) The Genetical Society of Great Britain, Heredity, 77, 113-129. 
Table 1 Allele frequencies for 13 enzyme-coding loci in five Algerian contact zone populations of Helix aspersa

\begin{tabular}{|c|c|c|c|c|c|c|}
\hline \multirow[b]{2}{*}{ Locus } & \multirow[b]{2}{*}{$\begin{array}{r}\text { Allele } \\
n:\end{array}$} & \multicolumn{5}{|c|}{ Population } \\
\hline & & $\begin{array}{c}A_{12} \\
15\end{array}$ & $\begin{array}{c}\mathrm{A}_{13} \\
35\end{array}$ & $\begin{array}{c}\mathrm{A}_{14} \\
32\end{array}$ & $\begin{array}{c}\mathrm{A}_{15} \\
31\end{array}$ & $\begin{array}{c}\mathrm{A}_{16} \\
25\end{array}$ \\
\hline \multirow[t]{5}{*}{ Lap-1 } & 100 & 0.100 & 0.543 & 0.641 & 0.323 & 0.320 \\
\hline & 94 & 0.133 & 0.000 & 0.000 & 0.000 & 0.000 \\
\hline & 96 & 0.500 & 0.357 & 0.000 & 0.548 & 0.620 \\
\hline & 98 & 0.267 & 0.043 & 0.297 & 0.097 & 0.040 \\
\hline & 103 & 0.000 & 0.057 & 0.063 & 0.032 & 0.020 \\
\hline \multirow[t]{13}{*}{ Lap-2 } & 100 & 0.767 & 0.486 & 0.266 & 0.323 & 0.520 \\
\hline & 86 & 0.000 & 0.000 & 0.016 & 0.000 & 0.000 \\
\hline & 88 & 0.000 & 0.000 & 0.031 & 0.000 & 0.000 \\
\hline & 90 & 0.000 & 0.043 & 0.375 & 0.000 & 0.000 \\
\hline & 92 & 0.033 & 0.000 & 0.000 & 0.000 & 0.000 \\
\hline & 94 & 0.033 & 0.214 & 0.172 & 0.097 & 0.140 \\
\hline & 96 & 0.033 & 0.114 & 0.141 & 0.016 & 0.240 \\
\hline & 98 & 0.000 & 0.000 & 0.000 & 0.032 & 0.000 \\
\hline & 103 & 0.000 & 0.071 & 0.000 & 0.161 & 0.000 \\
\hline & 105 & 0.133 & 0.071 & 0.000 & 0.065 & 0.060 \\
\hline & 108 & 0.000 & 0.000 & 0.000 & 0.194 & 0.000 \\
\hline & 110 & 0.000 & 0.000 & 0.000 & 0.113 & 0.000 \\
\hline & 115 & 0.000 & 0.000 & 0.000 & 0.000 & 0.040 \\
\hline \multirow[t]{4}{*}{ Got-1 } & 100 & 0.933 & 0.886 & 0.891 & 1.000 & 0.980 \\
\hline & 80 & 0.000 & 0.014 & 0.000 & 0.000 & 0.000 \\
\hline & 90 & 0.067 & 0.086 & 0.109 & 0.000 & 0.000 \\
\hline & 110 & 0.000 & 0.014 & 0.000 & 0.000 & 0.020 \\
\hline \multirow[t]{5}{*}{$M d h-1$} & 100 & 0.833 & 0.857 & 0.219 & 0.016 & 0.580 \\
\hline & 90 & 0.100 & 0.071 & 0.547 & 0.000 & 0.080 \\
\hline & 110 & 0.067 & 0.000 & 0.063 & 0.984 & 0.040 \\
\hline & 115 & 0.000 & 0.071 & 0.172 & 0.000 & 0.260 \\
\hline & 120 & 0.000 & 0.000 & 0.000 & 0.000 & 0.040 \\
\hline \multirow[t]{3}{*}{$M e-2$} & 100 & 0.867 & 0.814 & 1.000 & 1.000 & 1.000 \\
\hline & 90 & 0.067 & 0.129 & 0.000 & 0.000 & 0.000 \\
\hline & 110 & 0.067 & 0.057 & 0.000 & 0.000 & 0.000 \\
\hline \multirow[t]{3}{*}{$P g m-1$} & 100 & 0.967 & 0.971 & 1.000 & 0.968 & 0.660 \\
\hline & 85 & 0.033 & 0.000 & 0.000 & 0.000 & 0.000 \\
\hline & 90 & 0.000 & 0.029 & 0.000 & 0.032 & 0.340 \\
\hline \multirow[t]{4}{*}{$P g m-2$} & 100 & 0.633 & 0.886 & 0.859 & 0.274 & 0.540 \\
\hline & 80 & 0.000 & 0.014 & 0.000 & 0.016 & 0.000 \\
\hline & 90 & 0.367 & 0.043 & 0.141 & 0.710 & 0.460 \\
\hline & 110 & 0.000 & 0.057 & 0.000 & 0.000 & 0.000 \\
\hline \multirow[t]{3}{*}{$M p i-1$} & 100 & 1.000 & 0.829 & 0.953 & 1.000 & 0.980 \\
\hline & 98 & 0.000 & 0.000 & 0.031 & 0.000 & 0.000 \\
\hline & 103 & 0.000 & 0.171 & 0.016 & 0.000 & 0.020 \\
\hline \multirow[t]{3}{*}{ Pgi-2 } & 100 & 1.000 & 1.000 & 0.938 & 0.968 & 0.980 \\
\hline & 90 & 0.000 & 0.000 & 0.000 & 0.000 & 0.020 \\
\hline & 110 & 0.000 & 0.000 & 0.063 & 0.032 & 0.000 \\
\hline \multirow[t]{2}{*}{ Sod-1 } & 100 & 1.000 & 0.986 & 1.000 & 1.000 & 1.000 \\
\hline & 120 & 0.000 & 0.014 & 0.000 & 0.000 & 0.000 \\
\hline
\end{tabular}


Table 1 Continued

\begin{tabular}{|c|c|c|c|c|c|c|}
\hline \multirow[b]{2}{*}{ Locus } & \multirow[b]{2}{*}{$\begin{array}{r}\text { Allele } \\
n:\end{array}$} & \multicolumn{5}{|c|}{ Population } \\
\hline & & $\begin{array}{l}A_{12} \\
15\end{array}$ & $\begin{array}{l}\mathrm{A}_{13} \\
35\end{array}$ & $\begin{array}{c}\mathrm{A}_{14} \\
32\end{array}$ & $\begin{array}{c}\mathrm{A}_{15} \\
31\end{array}$ & $\begin{array}{l}A_{16} \\
25\end{array}$ \\
\hline \multirow[t]{4}{*}{$6 P g d-2$} & 100 & 1.000 & 0.943 & 0.906 & 0.371 & 0.180 \\
\hline & 90 & 0.000 & 0.000 & 0.000 & 0.081 & 0.000 \\
\hline & 110 & 0.000 & 0.057 & 0.063 & 0.516 & 0.820 \\
\hline & 115 & 0.000 & 0.000 & 0.031 & 0.032 & 0.000 \\
\hline \multirow[t]{6}{*}{ Est-3 } & 100 & 0.133 & 0.300 & 0.547 & 0.629 & 0.420 \\
\hline & 90 & 0.000 & 0.129 & 0.000 & 0.000 & 0.000 \\
\hline & 95 & 0.067 & 0.100 & 0.094 & 0.145 & 0.580 \\
\hline & 98 & 0.000 & 0.000 & 0.000 & 0.097 & 0.000 \\
\hline & 105 & 0.800 & 0.457 & 0.359 & 0.129 & 0.000 \\
\hline & 110 & 0.000 & 0.014 & 0.000 & 0.000 & 0.000 \\
\hline \multirow[t]{4}{*}{ Est-6 } & 100 & 0.933 & 0.357 & 0.375 & 0.113 & 0.000 \\
\hline & 98 & 0.067 & 0.057 & 0.094 & 0.000 & 0.000 \\
\hline & 103 & 0.000 & 0.586 & 0.531 & 0.823 & 1.000 \\
\hline & 106 & 0.000 & 0.000 & 0.000 & 0.065 & 0.000 \\
\hline
\end{tabular}

$n=$ sample size.

spondence analysis on the contingency table ' 32 samples $\times 35$ alleles' (42 rare alleles were projected as supplementary elements) (allelic frequencies at each locus and for each population are shown in Table 5, appendix). Figure 2a shows a projection on the principal plane of sample scores, complemented (Fig. 2b) by the partition into four classes based on the coordinates of these points on the three main factors. The first axis, which accounted for 25 per cent of the total variance, separated almost all populations according to their western (negative side) or eastern origin. Indeed, three colonies $\left(\mathrm{A}_{14}, \mathrm{~A}_{15}\right.$ and $A_{16}$ ) located at the boundary of these geographical entities presented an allelic composition close to the weighted average. The second axis ( 15 per cent of the total variance) reflected intraregion differentiation with the formation of two subclusters in each half plane; Littoral Skikda-Annaba and Tunisial South-East Bônois for the eastern group, and Algerois/Kabylia and West Algeria/Morocco for the western samples. The main alleles responsible for such spatial structuring coded for alternative allozymes of Mdh-1 (100, 110 and 115), Est-6 (100 and 103) and 6Pgd-2 (100 and 110) which were, respectively, more frequent in western and eastern populations (Table 1, Fig. 3). With regard to intermediate samples, $A_{13}$ and $\mathrm{A}_{12}$ deviated from independence in that $M d h-1(100)$ and Est-6(100) were found, respectively, at very high frequencies in these colonies.
The low contribution of three intermediate populations $\left(A_{14}, A_{15}\right.$ and $\left.A_{16}\right)$ to the axis of the east-west gradient of differentiation led us to examine these samples (plus $A_{12}$ and $A_{13}$ ) separately. Based on the contact zone previously defined, an analysis of individual typology was performed by applying a correspondence analysis on a multiple contingency table composed of 138 individuals (originated not only from $A_{14}, A_{15}$ and $A_{16}$ but also from $A_{12}$ and $A_{13}$ ) and described by 60 alleles. Figures $4 \mathrm{a}$ and $4 \mathrm{~b}$ illustrate the projection on the planes defined by the axes 1 and $2(1,2)$ and 1 and $3(1,3)$, respectively, of hierarchical clusters based on the point coordinates on the three first axes. As can be seen, these three main factors distinguished between eastern-western individuals, among eastern individuals and among western individuals, respectively. Indeed, three separate clusters appeared on each plane with few individuals overlapping. On the principal one, the most differentiated group included snails from $A_{15}$ which are almost all homozygotes $M d h-1(110 / 110)$. The shape of its cluster and the few peripheral points seen reflected the existence of rare genotypes in this population. On the other hand, the least differentiated individuals were those from Djemila $\left(\mathrm{A}_{14}\right)$. They were assigned to the western subcluster but close to the origin of the axes. Such an intermediate position arose from atypical alleles belonging either to western or eastern samples, but also to specific 


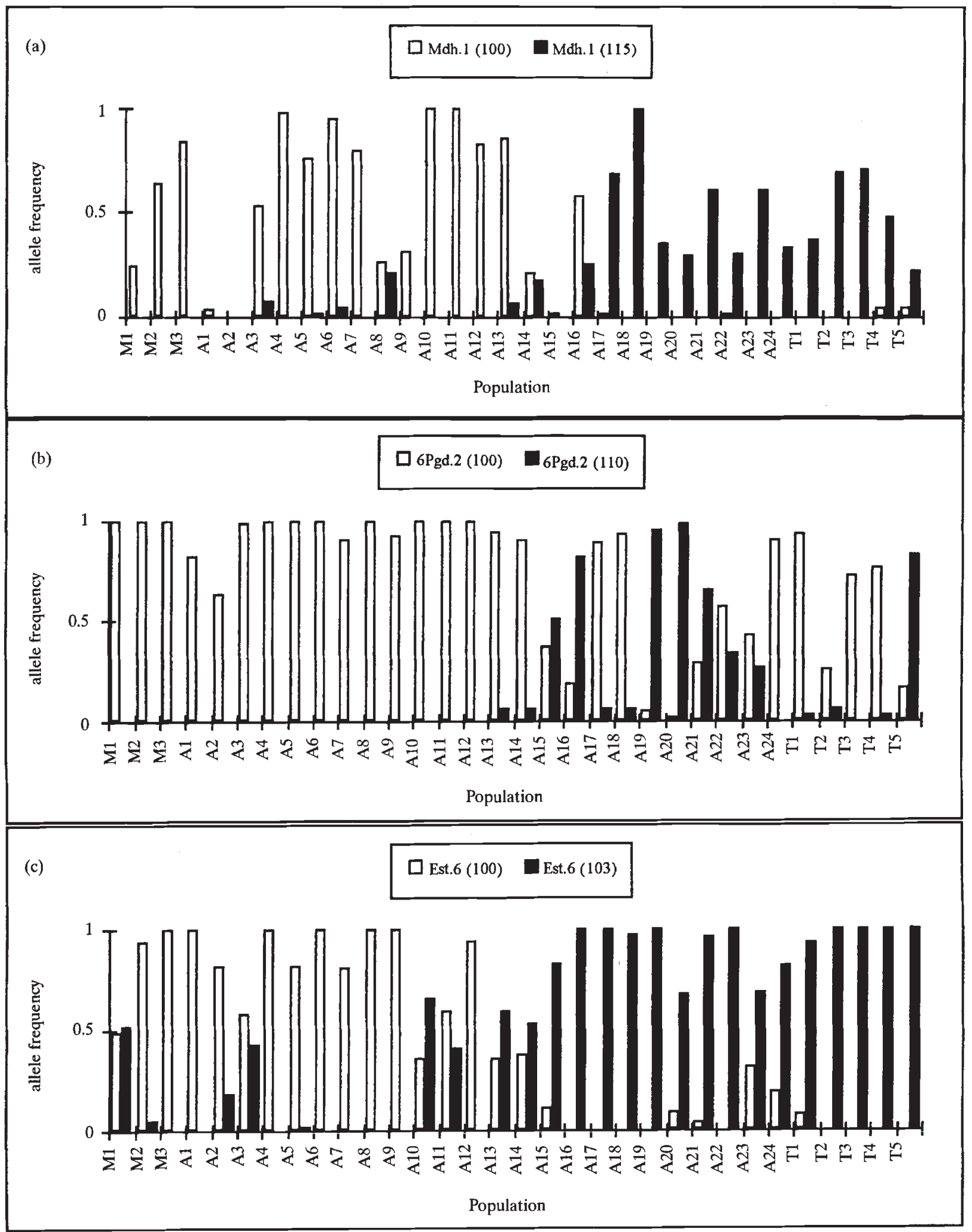

Fig. 3 Geographical distribution of the mean frequency of alternative alleles at (a) Mdh-1, (b) $6 P g d-2$ and (c) Est-6 in Maghreb populations of Helix aspersa. 
(a)

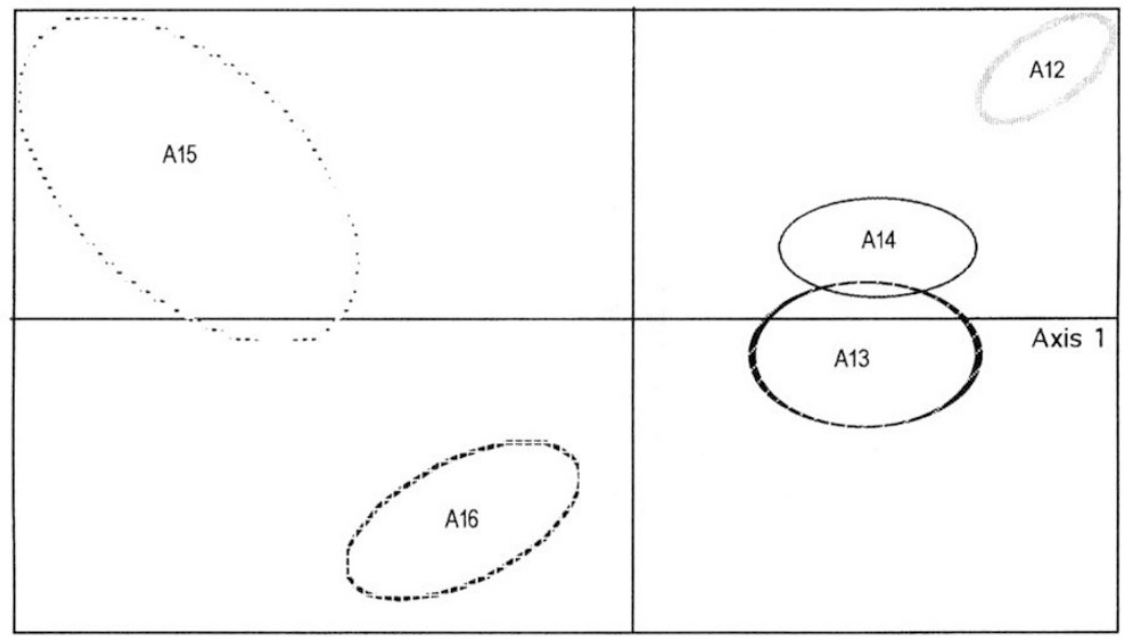

(b)

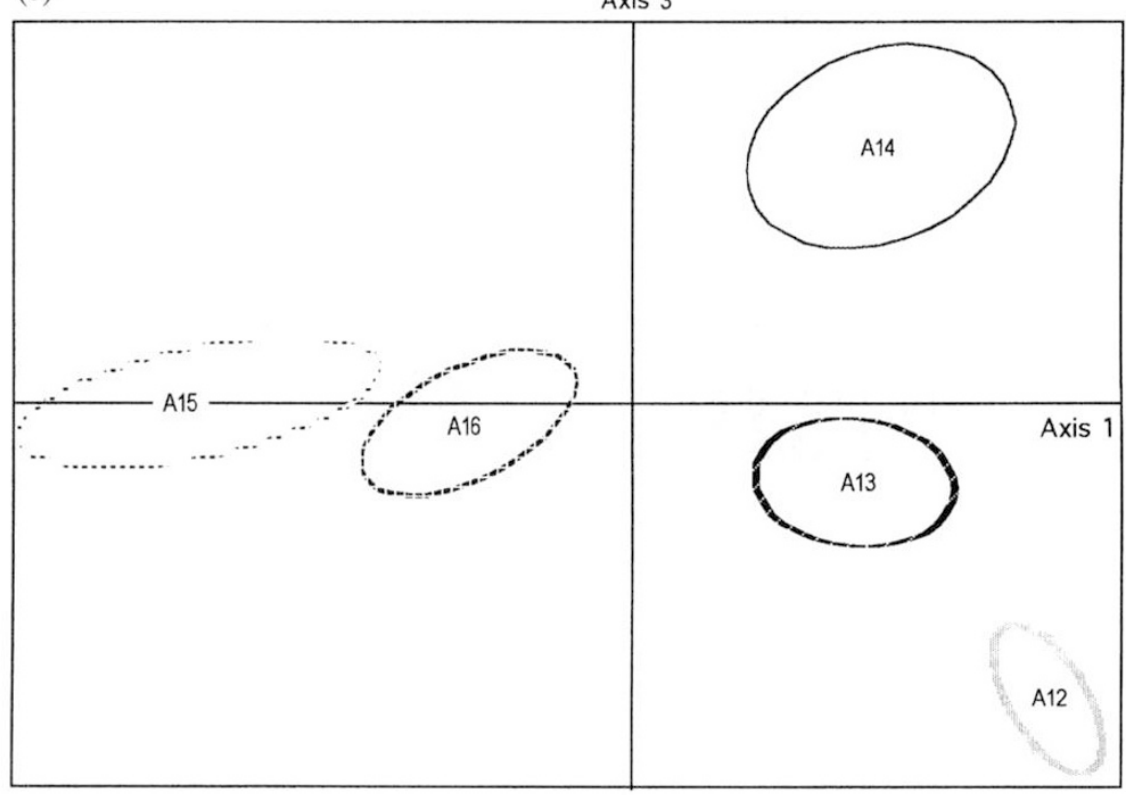

Fig. 4 (a) Principal plane and (b) plane $(1,3)$ of the CA on a multiple contingency table composed of 138 contact zone Helix aspersa and 60 alleles. Projection of main hierarchical clusters obtained. markers which were rare, indeed private. The third factor strengthened the influence of these allele combinations in the differentiation of $A_{14}$ because corresponding snails spread out more along this axis because of either more frequent $[M d h-1(90)$ and Lap-2(90)] or exclusive [Lap-2(86, 88)] allozymes.

The CA based on the contingency table ' 5 samples $\times 60$ alleles' lets us know the respective contribution of populations in the determination of axes and, accordingly, to appreciate better divergences among them. The three first axes accounted, respectively, for 45.3 per cent, 24.2 per cent and 19.9 per cent of the total variance. It was found that interdeme variation was stronger among the eastern populations $\left(A_{15}, A_{16}\right)$ than among the western ones $\left(A_{12}, A_{13}, A_{14}\right)$. Exact tests for population differentiation confirmed such a distinction with the number of loci generating significant differences being slightly higher between eastern samples than between western ones (Table 2). The markers responsible for such intraregion variation were alternate allozymes of Lap-1, Lap-2, Est-3 and especially those of $6 P g d-2, M d h-1$ and Est-6. With regard to interregion variation, the largest divergence arose between $A_{13}$ and $A_{15}$ with 10 loci showing significant differences. 
Table 2 Significantly different loci for all pairs of contact zone populations of Helix aspersa

\begin{tabular}{|c|c|c|c|c|}
\hline Population & $A_{13}$ & $\mathrm{~A}_{14}$ & $\mathrm{~A}_{15}$ & $\mathrm{~A}_{16}$ \\
\hline $\mathrm{A}_{12}$ & $\begin{array}{l}\text { Lap-1 } 1^{* * *}, \text { Lap-2*** } \\
\text { Pgm-2***, Mpi-1* } \\
\text { Est-3* } \text { - Est-6 }^{* * *}\end{array}$ & $\begin{array}{l}\text { Lap-1***, Lap-2*** } \\
\text { Mdh-1***, Me-2** } \\
\text { Est }-3^{* * *}, \text { Est } 6^{* * *}\end{array}$ & $\begin{array}{l}\text { Lap-1 } 1^{* * *}, \text { Lap-2* } \\
\text { Mdh-1***, Pgm-2*** } \\
6 \text { Pgd-2***, Est-3*** } \\
\text { Est-6*** }\end{array}$ & 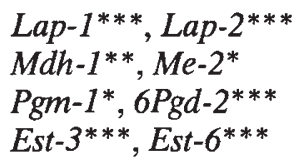 \\
\hline$A_{13}$ & - & $\begin{array}{l}\text { Lap }-1^{* * *}, \text { Lap-2*** } \\
\text { Mdh-1***, Me-2*** } \\
\text { Pgm- } 2^{*}, \text { Mpi-1** } \\
\text { Pgi-2* }, \text { Est }-3^{* *}\end{array}$ & 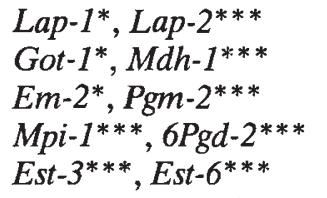 & $\begin{array}{l}\text { Lap }-1^{*}, \text { Lap }-2^{* *} \\
\text { Mdh-1 } 1^{* * *}, M e-2^{* *} \\
\text { Pgm-2***, Mpi-1 } 1^{* *} \\
\text { 6Pgd-2***, Est-3*** } \\
\text { Est-6*** }\end{array}$ \\
\hline $\mathrm{A}_{14}$ & - & - & $\begin{array}{l}\text { Lap-1 } 1^{* * *}, \text { Lap }-2^{* * *} \\
\text { Got }-1^{*}, \text { Mdh }-1^{* * *} \\
\text { Pgm-2***, } 6 \text { Pgd-2*** } \\
\text { Est }-3^{* * *}, \text { Est }-6^{* * *}\end{array}$ & 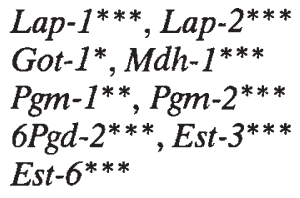 \\
\hline $\mathrm{A}_{15}$ & - & - & - & $\begin{array}{l}\text { Lap-2***, Mdh-1*** } \\
\text { Pgm-1 } 1^{*}, \text { Pgm- } 2^{* *} \\
6 \text { Pgd-2**, Est-3*** } \\
\text { Est-6** }\end{array}$ \\
\hline
\end{tabular}

Exact test for population differentiation: ${ }^{*} P<0.05$; ${ }^{* *} P<0.01 ;{ }^{* *} P<0.001$.

Fisher test to combine independent test results: $\chi_{14}^{2}=69.3, P<0.001$.

Estimates of $\mathrm{Nm}$ between each pair of populations and within each region tallied with some previous results. Indeed, gene flow was obviously higher in the west than in the east (3.7 vs. 1.01; $\chi_{1}^{2}=4.2, P=0.038$ ), and except for the pair $\mathrm{A}_{12}-\mathrm{A}_{14}$ $(\mathrm{Nm}=0.47)$, intraregion values of $\mathrm{Nm}$ were greater than 1. Furthermore, extreme values occurred between $\mathrm{A}_{12}$ and $\mathrm{A}_{16}[\mathrm{Nm}=0.17$ with a conditional average frequency $p(1)=0.26$ ] for the lower rate, i.e. between the most distant stations, and between $\mathrm{A}_{13}$ and $\mathrm{A}_{14}$ for the higher one $(\mathrm{Nm}=1.42$; $p(1)=0.06)$. The average frequencies of private alleles decreased in the case of adjacent populations.

\section{Wahlund effect with one and two genes}

Mean heterozygosities in the various populations showed marked variation among loci; the range of expected average values for polymorphic loci was from 0.006 for Sod-1 to 0.667 for Lap-2 (Table 3). At the population level, the most variable deme was $\mathrm{A}_{13}$ with a mean value of $H_{\mathrm{e}}=0.285 \pm 0.249$. The mean weighted $F_{\text {IS }}$-value summed across all polymorphic loci reflected clearly the impact of nonrandom mating within populations because it was significantly different from zero $\left(F_{\mathrm{IS}}=0.170 \pm 0.038\right)$ (Table 4). Apart from $\mathrm{Me}-2$, the main loci which showed this global homozygote excess were the most variable and those with the highest numbers of alleles such as Lap-1, Est-3 and Est-6 (the existence of only one or two uncommon homozygotes within $\mathrm{A}_{12}$ and $\mathrm{A}_{13}$ explains the very high Me-2 value). Inbreeding variation within the population resulting from random genetic drift was even larger $\left(F_{\mathrm{ST}}=0.270 \pm 0.066, P<0.001\right)$. However, the population subdivision did not affect all loci equally and among the most informative ones, greatest divergences occurred at $M d h-1,6 P g d-2$ and Est-6; that is to say, in the main loci showing clinal variation from West to East Maghreb.

Exact test results for Hardy-Weinberg equilibrium led us to identify these departures within samples and to know the genotypic classes which were too small (Table 3). Significant departures from Hardy-Weinberg proportions, which were all heterozygote deficiencies, occurred at the loci mentioned above plus Pgd-2 and Lap-2. These loci, which were the same in the populations, were those coding for introgressed alleles. In addition, in $A_{13}$ and $\mathrm{A}_{14}$, deviations observed at Lap-1 arose from two allozymes clearly more frequent in the west, namely Lap-1(96) in $\mathrm{A}_{13}$ and Lap-1(98) in $\mathrm{A}_{14}$. In a similar way, two of the best diagnostic markers in the east, i.e. Est-6(103) and 6Pgd-2(110), caused heterozygote deficiencies in $\mathrm{A}_{13}$ and $\mathrm{A}_{15}$, respectively.

Exact tests for genotypic disequilibrium indicated significant departures $(P<0.05)$ from random assort- 
Table 3 Observed $\left(H_{\mathrm{o}}\right)$ and expected $\left(H_{\mathrm{e}}\right)$ mean heterozygosities and significant deviations $(D)$ from Hardy-Weinberg expectations for contact zone populations of Helix aspersa (exact Hardy-Weinberg probability by the Markov chain method was performed for each locus in each population; Fisher's method used to combine loci, population and populations/loci test results)

\begin{tabular}{|c|c|c|c|c|c|c|c|c|c|c|c|c|c|c|}
\hline Population & & Lap-1 & Lap-2 Got-1 & $M d h-1$ & $M e-2$ & Pgm-1 & Pgm-2 & $M p i-1$ & Pgi-2s & Sod-1 & $6 P g d-2$ & Est-3 & Est-6 & $\begin{array}{l}\text { Fisher } \\
\text { test }\end{array}$ \\
\hline$A_{12}$ & $\begin{array}{c}H_{\mathrm{o}} \\
H_{\mathrm{e}} \\
D\end{array}$ & $\begin{array}{l}0.667 \\
0.674\end{array}$ & $\begin{array}{ll}0.467 & 0.133 \\
0.405 & 0.129\end{array}$ & $\begin{array}{c}0.067 \\
0.301 \\
d^{* *}\end{array}$ & $\begin{array}{l}0.133 \\
0.248\end{array}$ & $\begin{array}{l}0.067 \\
0.067\end{array}$ & $\begin{array}{l}0.200 \\
0.480\end{array}$ & - & - & - & - & $\begin{array}{c}0.267 \\
0.349 \\
d^{*}\end{array}$ & $\begin{array}{l}0.133 \\
0.129\end{array}$ & $\begin{array}{l}\chi_{16}^{2}=30.4 \\
P=0.016\end{array}$ \\
\hline$A_{13}$ & $\begin{array}{c}H_{\mathrm{o}} \\
H_{\mathrm{e}} \\
D\end{array}$ & $\begin{array}{l}0.314 \\
0.581 \\
d^{* * *}\end{array}$ & & $\begin{array}{l}0.257 \\
0.259\end{array}$ & $\begin{array}{c}0.200 \\
0.322 \\
d^{*}\end{array}$ & $\begin{array}{l}0.057 \\
0.056\end{array}$ & $\begin{array}{l}0.229 \\
0.213\end{array}$ & $\begin{array}{l}0.286 \\
0.288\end{array}$ & - & $\begin{array}{l}0.029 \\
0.029\end{array}$ & $\begin{array}{l}0.114 \\
0.109\end{array}$ & & $\begin{array}{l}0.257 \\
0.534 \\
d^{* * *}\end{array}$ & $\begin{array}{l}\chi_{22}^{2}=51.1 \\
P=0.000\end{array}$ \\
\hline$A_{14}$ & $\begin{array}{c}H_{\mathrm{o}} \\
H_{\mathrm{e}} \\
D\end{array}$ & $\begin{array}{l}0.250 \\
0.505 \\
d^{* * *}\end{array}$ & $\begin{array}{ll}0.750 & 0.219 \\
0.750 & 0.198\end{array}$ & $\begin{array}{l}0.719 \\
0.629\end{array}$ & - & - & $\begin{array}{l}0.281 \\
0.246\end{array}$ & $\begin{array}{l}0.094 \\
0.092\end{array}$ & $\begin{array}{l}0.125 \\
0.119\end{array}$ & - & $\begin{array}{l}0.188 \\
0.177\end{array}$ & $\begin{array}{l}0.344 \\
0.572 \\
d^{* * *}\end{array}$ & $\begin{array}{l}0.563 \\
0.577\end{array}$ & $\begin{array}{l}\chi_{20}^{2}=33.2 \\
P=0.032\end{array}$ \\
\hline$A_{15}$ & $\begin{array}{c}H_{\mathrm{o}} \\
H_{\mathrm{e}} \\
D\end{array}$ & $\begin{array}{l}0.387 \\
0.594\end{array}$ & $\begin{array}{l}0.645 \\
0.818- \\
d^{* * *}\end{array}-$ & $\begin{array}{l}0.032 \\
0.032\end{array}$ & - & $\begin{array}{l}0.065 \\
0.063\end{array}$ & $\begin{array}{l}0.385 \\
0.428\end{array}$ & - & $\begin{array}{l}0.065 \\
0.063\end{array}$ & - & $\begin{array}{c}0.387 \\
0.598 \\
d^{* *}\end{array}$ & $\begin{array}{c}0.355 \\
0.566 \\
d^{* *}\end{array}$ & $\begin{array}{l}0.290 \\
0.311\end{array}$ & $\begin{array}{l}\chi_{16}^{2}=28.9 \\
P=0.025\end{array}$ \\
\hline 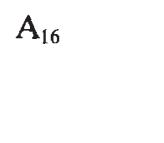 & $\begin{array}{c}H_{\mathrm{o}} \\
H_{\mathrm{e}} \\
D\end{array}$ & $\begin{array}{l}0.560 \\
0.522\end{array}$ & $\begin{array}{cc}0.440 & 0.040 \\
0.660 & 0.040 \\
d^{*} & \end{array}$ & $\begin{array}{l}0.600 \\
0.598\end{array}$ & - & $\begin{array}{l}0.680 \\
0.458\end{array}$ & $\begin{array}{l}0.520 \\
0.507\end{array}$ & $\begin{array}{l}0.040 \\
0.040\end{array}$ & $\begin{array}{l}0.040 \\
0.040\end{array}$ & - & $\begin{array}{l}0.360 \\
0.301\end{array}$ & $\begin{array}{c}0.200 \\
0.497 \\
d^{*}\end{array}$ & - & $\begin{array}{c}\chi_{14}^{2}=22.0 \\
\text { NS }\end{array}$ \\
\hline
\end{tabular}

Fisher $\quad \chi_{10}^{2}=38.1$ NS NS $\chi_{8}^{2}=18.3 \chi_{6}^{2}=31.1 \quad$ NS NS NS NS $\quad$ N.S. $\chi_{10}^{2}=44.9 \chi_{18}^{2}=17.6 \chi_{88}^{2}=165.6$ $\begin{array}{lll}P=0.000 & P=0.019 P=0.042 & P=0.000 P=0.024 P=0.000\end{array}$

$d$, heterozygote deficiency; ${ }^{*} P<0.05,{ }^{* *} P<0.01,{ }^{* * *} P<0.001$.

$\dagger$ Analysis not possible because Sod-1 is a quasi-monomorphic locus.

ment expectations for only eight pairwise combinations of alleles when all populations were assessed individually. $A_{15}$ and the less variable sample $A_{12}$ showed no linkage disequilibrium whereas one and five significant associations were found at $\mathrm{El}$ Hedaick $\left(\mathrm{A}_{16}\right.$; between Lap-1/Lap-2, P=0.044) and at Djemila $\left(\mathrm{A}_{14}\right)$, respectively. Within Djemila, variations from expected values arose from loci having alternate alleles responsible for most intraregion differentiation (i.e. Lap-1, Est-3, Est-6, Mdh-1; $P<0.05)$, two of them (Lap-1 and Est-3) being characterized by heterozygote deficiencies.

\section{Discussion}

The results from this study confirm some of our previous findings (Guiller et al., 1994): the populations analysed, $\mathrm{A}_{12}, \mathrm{~A}_{13}, \mathrm{~A}_{14}, \mathrm{~A}_{15}$ and $\mathrm{A}_{16}$, really belong to two well-differentiated geographical regions, but although the sample of Djemila $\left(\mathrm{A}_{14}\right)$ is close to western stations $\left(\mathrm{A}_{12}\right.$ and $\left.\mathrm{A}_{13}\right)$, both the variations in allele frequencies and genetic structure suggest that it has been in contact with eastern Algerian populations. However, so far this hybrid zone has not yielded enough information (in term of samples and enzymatic loci) to give the geographical and genetic detail required for a full analysis. Indeed, our data are insufficient to determine the nature and the respective strength of the opposing forces of migration and selection [which tend to broaden and narrow the zone, respectively (Barton \& Hewitt, 1985)], the number of loci under selection, or the barrier strength to gene flow (Szymura \& Barton, 1991). Furthermore, the littoral location of nearly all of the samples collected approximately creates a transect, and such a model is expected to reveal only a gradual change in the mean of a character. Other possible forms of geographical variation, such as a mosaic distribution of characters, could, however, be found using a more complete data network. In addition to this spatial component, another limit to our conclusions comes from the lack of information on temporal variation. In such a 
Table 4 Estimates of Wright's $F$-statistics according to Weir \& Cockerham's (1984) modification in the five suspected contact zone populations of Helix aspersa

\begin{tabular}{|c|c|c|c|}
\hline Locus & $F_{\text {IS }}$ & $F_{\mathrm{ST}}$ & $F_{\text {IT }}$ \\
\hline Lap-1 & 0.300 & 0.172 & 0.430 \\
\hline $\mathrm{SD}$ & 0.106 & 0.149 & 0.124 \\
\hline Lap-2 & 0.148 & 0.095 & 0.226 \\
\hline SD & 0.062 & 0.050 & 0.039 \\
\hline Got-1 & -0.025 & 0.027 & 0.002 \\
\hline SD & 0.058 & 0.008 & 0.060 \\
\hline$M d h-1$ & 0.015 & 0.604 & 0.615 \\
\hline SD & 0.107 & 1.496 & 0.276 \\
\hline$M e-2$ & 0.388 & 0.078 & 0.437 \\
\hline SD & 0.072 & 0.024 & 0.076 \\
\hline Pgm-1 & -0.131 & 0.083 & -0.043 \\
\hline $\mathrm{SD}$ & 0.075 & 0.022 & 0.020 \\
\hline$P g m-2$ & 0.055 & 0.352 & 0.387 \\
\hline $\mathrm{SD}$ & 0.088 & 0.454 & 0.163 \\
\hline$M p i-1$ & 0.016 & 0.171 & 0.186 \\
\hline $\mathrm{SD}$ & 0.011 & 0.046 & 0.101 \\
\hline$P g i-2$ & -0.039 & 0.018 & -0.022 \\
\hline SD & 0.021 & 0.002 & 0.014 \\
\hline Sod-1 & 0.008 & -0.009 & -0.001 \\
\hline SD & 0.004 & 0.000 & 0.001 \\
\hline $6 P g d-2$ & 0.200 & 0.478 & 0.544 \\
\hline $\mathrm{SD}$ & 0.244 & 1.213 & 0.053 \\
\hline Est-3 & 0.266 & 0.185 & 0.408 \\
\hline SD & 0.147 & 0.218 & 0.155 \\
\hline Est-6 & 0.241 & 0.311 & 0.468 \\
\hline $\mathrm{SD}$ & 0.202 & 0.681 & 0.199 \\
\hline Mean & $0.170 * * *$ & $0.270 * * *$ & $0.396^{* * *}$ \\
\hline & 0.038 & 0.066 & 0.049 \\
\hline
\end{tabular}

SD, jackknife estimate of standard deviation over 13 polymorphic loci.

${ }^{* * *} P<0.001$ ( $t$-test $)$.

historical context, a hybrid zone should also be analysed over the dimension of time (Arntzen \& Wallis, 1991).

\section{Common and rare allozymes: two kinds of information}

With regard to the degree of genetic divergence among the five populations studied, only the variation in alleles present with moderate or high frequencies over the whole of the Maghreb popula- tions allows us to ascertain the intermediate position of $\mathrm{A}_{14}$. Markers responsible for this partitioning are mainly eastern alleles introgressed in this population, such as $M d h-1(90,115)$ and especially Est-6(103). On the other hand, the pattern of migration relying on private alleles found step-by-step among adjacent populations does not reveal greater genetic exchanges between Djemila and eastern samples. Moreover, the highest rate of inter-region migration, of less than one migrant every generation, arises from $A_{13}$. Thus, it is tempting to ascribe such discrepancies between the patterns of gene exchanges to the times since contact occurred among these populations. Indeed, gene flow may have occurred for a long time in this low migration species, although it may not still be continuing. Because alleles which differentiated adjacent populations are low frequency markers sporadically distributed over the Maghreb territory, they have probably been locally eliminated under the effects of genetic drift, mutation and/or selection as a result of their having low frequencies in the ancestral population (Slatkin, 1985). It is, however, surprising to observe so many private alleles among adjoining populations, an average of 19 alleles instead of the $13\left(\chi_{1}^{2}=4.1\right.$, $P=0.04)$ found in the remaining Maghreb colonies (Guiller et al., 1994; Guiller, Bellido \& Madec, unpublished observations). Such an increase in the frequency of rare alleles in hybridizing populations has been described in many other species, and especially (considering terrestrial molluscs only) in the well-studied land snails Partula (Clarke, 1968) and Cerion (Woodruff, 1981, cited by Barton et al., 1983; Woodruff, 1989). Furthermore, allozymes that are unique to interspecific hybrid zones (Woodruff, 1989) could include the electromorph Lap-2(86) which has been found in only one sample of $H$. aspersa studied, i.e. the one from Djemila. Several mechanisms, including higher mutation rate and relaxed selection, have been proposed to explain both the production and maintenance of these peculiar allelic variants, but they cannot reliably be distinguished (Barton et al., 1983; Barton \& Hewitt, 1985; Woodruff, 1989). Whatever is the explanation for such a local increase in peculiar allozymes, introgressed and private alleles apparently lead to different patterns of migration but both reflect the existence of gene exchanges between western and eastern populations.

\section{Possible effects of population mixing}

It is obviously tempting to interpret deficits of heterozygotes and genotypic linkage disequilibria 
found across this suspected hybrid zone in terms of mixture between populations, especially because most of the significant associations between loci appear in the central station of Djemila. Although such findings occur widely in other species and reflect the genetic structure of the hybridizing populations, our data are insufficient to demonstrate their significance. It is particularly true for heterozygote deficiencies. Indeed, such deviations from Hardy-Weinberg expectations are not specific to these five intermediate populations as they arise in almost all Maghreb populations $\left(F_{\text {IS }}=0.203\right.$, $P<0.001$ ), and more generally, in all populations of $H$. aspersa studied (Madec, 1991; Lazaridou-Dimitriadou et al., 1993; A. Guiller, L. Madec \& M. A. Coutellec-Vreto, unpublished observations). Moreover, these deviations from panmixia have been commonly found in many electrophoretic surveys of Molluscan species, for instance in Cepaea spp. (Guiller \& Madec, 1991, 1993). Thus, it is evident that the Wahlund effect cannot be the single possible cause to consider and several other explanations proposed in the literature should also be taken into account, some coming under the selection hypothesis and others under the neutrality hypothesis. Among the latter, linkage disequilibria are especially interesting because of the statistical genotypic dependences observed. The question now is whether these departures from Hardy-Weinberg proportions are caused - in addition to likely natural selection as well as limited migration and random genetic drift (Ohta, 1982a,b) and by real nonrandom associations between alleles of different loci or by an admixture of populations with differing gametic frequencies. Epistatic interactions are unlikely as in all sexually reproductive species, because of a high level of recombination between genes. Even so, some studies have suggested the existence of such disequilibria. Indeed, significant values of $D$ have been found in natural populations of Drosophila (Hartl \& Clark, 1989), and also in several of those of $C$. nemoralis recently introduced in New York (Selander \& Foltz, 1981). However, genes found in linkage disequilibria in both cases were some of the esterase loci whereas most of the markers involved here are in genes which are probably not so tightly linked. Thus, it would seem that rather than through selection or genetic drift, linkage disequilibria would probably arise as the product of exchanges between populations having distinct gene pools, such as Djemila and the eastern ones. Moreover, the approach to linkage equilibrium would be retarded because of a quite low migration rate (Nei \& Li, 1973).

\section{When would contacts have been?}

In a previous paper, three scenarios related to dispersal and vicariant events have been considered to explain the disjunct distribution of $H$. aspersa observed in Maghreb and Europe, and to determine the processes responsible for geographical isolation in the eastern part of Maghreb (Guiller et al., 1994). The most suitable refers to climatic events which occurred during the Quaternary. Then, peripheral populations from both East and West Maghreb would have regained contact after having been isolated during the glacial period. Evidence in favour of this contact model is the West-East clinal decrease in diverticulum length (Madec \& Guiller, 1994). Indeed, hybridizing populations and especially those from Djemila $\left(\mathrm{A}_{14}\right)$, El Ancer $\left(\mathrm{A}_{15}\right)$ and El Hedaick $\left(A_{16}\right)$ have middle-sized diverticula compared with eastern and western ones $(68.8 \mathrm{~mm}$ in the west, $64.4 \mathrm{~mm}$ in the contact zone but only $59.0 \mathrm{~mm}$ after removing $A_{12}$ and $A_{13}$, and $39.1 \mathrm{~mm}$ in the east). At this stage in the investigation, it is obvious that in addition to examining further samples, other criteria should be analysed to investigate more thoroughly the dynamics of exchanges across this hybrid zone. Without ruling out the possible effect of migration between distinct populations, it would be essential in the first place to investigate thoroughly the genetic structure of populations in order to redefine the panmictic unit of the species. Because of heterozygote deficiencies commonly found in molluscan species, it may be questioned whether individuals sampled in one presumed population really belong to the same demographical unit. As in many evolutionary studies, it would also be of great importance to have information on the variation in mitochondrial DNA to know if these cytoplasmic markers reflect the same or differing historical patterns of introgression. Thus, if western and eastern populations also differ clearly in their mtDNA composition, it may be speculated that in contact zone populations, for instance in Djemila, haplotypes characteristic of both Maghreb areas may be found.

\section{Acknowledgements}

We thank M. Raymond and F. Rousset for placing the first test version of GENEPOP at our disposal. We also express our gratitude to anonymous referees for helpful comments on the manuscript. A. G. thanks Dr J. F. Y. Brookfield for careful reading of the manuscript and useful suggestions. 


\section{References}

ADDAD, 1992. Logiciel de traitement, version micro 92. Association pour le Développement et la Diffusion de l'Analyse des Données, Paris.

ARNTZEN, J. W. AND WALLIS, G. P. 1991. Restricted gene flow in a moving hybrid zone of the newts Triturus cristatus and T. marmoratus in western France. Evolution, 45, 805-826.

BARTON, N. H. AND HEwITT, G. M. 1985. Analyses of hybrid zones. Ann. Rev. Ecol. Syst., 16, 113-148.

BARTON, N. H. AND SLATKIN, M. 1986. A quasi-equilibrium theory of the distribution of rare alleles in a subdivided population. Heredity, 56, 409-415.

BARTON, N. H., HALLIDAY, R. B. AND HEWITT, G. M. 1983. Rare electrophoretic variants in a hybrid zone. Heredity, 50, 139-149.

BENZECRI, J. P. 1973. L'Analyse des Données. Dunod, Paris.

CAIN, A. J. AND CURREY, J. D. 1963. Area effects in Cepaea.

Phil. Trans. R. Soc. B, 246, 1-83.

CLARKE, B. 1968. Balanced polymorphism and regional differentiation in land snails. In: Drake, E. T. (ed.) Evolution and Environment, pp. 351-368. Yale University Press, New Haven, CT.

ESCOFIER, B. AND PAGES, J. 1990. Analyses Factorielles Simples et Multiples - Objectif, Méthodes et Interprétation, 2nd edn. Dunod, Paris.

GOULD, s. J. AND wOODRUFF, D. s. 1978. Natural history of Cerion, VIII: Little Bahama Bank - a revision based on genetics, morphometrics, and geographic distribution. Bull. Mus. Comp. Zool. Harvard Univ., 148, 371-415.

GUILLER, A. AND MADEC, L. 1991. Variabilité enzymatique dans quelques populations naturelles de Cepaea nemoralis et Cepaea hortensis en France. C. r. Acad. Sci. Paris, 313, 299-306.

GUILLER, A. AND MADEC, L. 1993. A contribution to the study of morphological and biochemical differentiation in French and Iberian populations of Cepaea nemoralis. Biochem. Syst. Ecol., 3, 323-339.

GUILLER, A., MADEC, L. AND DAGUZAN, J. 1994. Geographical patterns of differentiation in the landsnail Helix aspersa Müller (Gastropoda: Pulmonata). J. Moll. Stud., 60, 205-221.

GUO, s. W. AND tHOMPSON, E. A. 1992. Performing the exact test of Hardy-Weinberg proportion for multiple alleles. Biometrics, 48, 361-372.

HARrison, R. G. (ed.) 1993. Hybrid Zones and the Evolutionary Process. Oxford University Press, New York.

harTL, D. L. AND ClARK, A. G. 1989. Principles of Population Genetics. Sinauer Associates, Sunderland, MA.

JoHnson, M. s. 1976. Allozymes and area effects in Cepaea nemoralis on the western Berkshire Downs. Heredity, 36, 105-121.

JOHNSON, M. S., MURRAY, J. AND CLARKE, B. 1993. The ecological genetics and adaptative radiation of Partula on Moorea. Oxf. Surv. Evol. Biol., 9, 167-238.

JONES, J. S., SELANDER, R. K. AND SCHNELL, G. D. 1980. Patterns of morphological and molecular polymorphism in the land snail Cepaea nemoralis. Biol. J. Linn. Soc.,
14, 359-357.

LAZARIDOU-DIMITRIADOU, M., KARAKOUSIS, Y. AND STAIKOU, A. 1993. Geographic variation in shell morphology and isoenzymes of Helix aspersa Müller, 1774 (Gastropoda, Pulmonata), the edible land snail, from Greece and Cyprus. Heredity, 71, 434-447.

LOU1S, E. J. AND DEMPSTER, E. R. 1987. An exact test for Hardy-Weinberg and multiple alleles. Biometrics, 43, 805-811.

MADEC, L. 1989. Etude de la Differenciation de Quelques Populations Géographiquement Isolées de l'Espèce Helix Aspersa Müller (Mollusque Gastéropode Pulmoné): Aspects Morphologiques, Ecophysiologiques et Biochimiques. Ph.D. Thesis, University of Rennes.

MADEC, L. 1991. Variabilité enzymatique dans quelques populations naturelles de l'espèce Helix aspersa Müller. C. r. Acad. Sci. Paris, 313, 339-344.

MADEC, L. AND GUILLER, A. 1994. Geographic variation of distal genitalia in the landsnail Helix aspersa Müller. $J$. Zool., 233, 215-231.

NEI, M. AND LI, W. H. 1973. Linkage disequilibrium in subdivided populations. Genetics, 75, 213-219.

OHTA, т. 1982a. Linkage disequilibrium due to random genetic drift in finite subdivided populations. Proc. Natl. Acad. Sci. U.S.A., 79, 1940-1944.

OHTA, T. 1982b. Linkage disequilibrium with the island model. Genetics, 101, 139-155.

RAYMOND, M. AND ROUSSET, F. 1994. GENEPOP Version 1.0. University des Sciences et Techniques du Languedoc, Montpellier.

RAYMOND, M. AND ROUSSET, F. 1995a. GENEPOP (Version 1.2): a population genetics software for exact tests and ecumenicism. J. Hered., 86, 248-249.

RAYMOND, M. AND ROUSSET, F. 1995b. An exact test for population differentiation. Evolution, 49, 1280-1283

ROUSSET, F. AND RAYMOND, M. 1995. Testing heterozygote excess and deficiency. Genetics, 140, 1413-1419.

RICE, w. R. 1989. Analyzing tables of statistical tests. Evolution, 43, 223-225.

SELANDER, R. K. AND FOLTZ, D. w. 1981. Gametic disequilibrium between esterase loci in populations of Cepaea nemoralis in western New York. Evolution, 35, 190-192.

SHE, J. X., AUTEM, M., KOTULAS, G., PASTEUR, N. AND BONHOMME, F. 1987. Multivariate analysis of genetic exchanges between Solea aegyptiaca and Solea senegalensis (Teleosts, Soleidae). Biol. J. Linn. Soc., 32, 357-371.

SLATKIN, M. 1985. Rare alleles as indicators of gene flow. Evolution, 39, 53-65.

SWOFFORD, D. L. AND SELANDER, R. B. 1989. BIOSYS-1. A computer program for the analysis of allelic variation in population genetics and biochemical systematics. Release 1.7. In: Swofford, D. L. (ed.) Illinois Natural History Survey, pp. 1-43. Champaign, IL.

SZYMURA, J. M. AND BARTON, N. H. 1991. The genetic structure of the hybrid zone between the fire-bellied toads Bombina bombina and $B$. variegata: comparisons between transects and between loci. Evolution, 45, 237-261. 
TAYLOR, J. W. 1913. Monograph of the Land and Freshwater Mollusca of the British Isles, pp. 236-273. Taylor Brothers, Leeds.

WEIR, B. S. AND COCKERHAM, C. C. 1984 . Estimating $F$-statistics for the analysis of population structure. Evolution, 38, 1358-1370.

wOODRUFF, D. S. 1989. Genetic anomalies associated with Cerion hybrid zones: the origin and maintenance of new electrophoretic variants called hybrizymes. Biol. J. Linn.
Soc, 36, 281-294.

WOODRUFF, D. S. AND GOULD, s. J. 1987. Fifty years of interspecific hybridization: genetics and morphometrics of a controlled experiment on the landsnail Cerion in Florida Keys. Evolution, 41, 1022-1045.

WRIGHT, s. 1965. The interpretation of population structure by F-statistics with special regard to systems of mating. Evolution, 19, 395-420. 


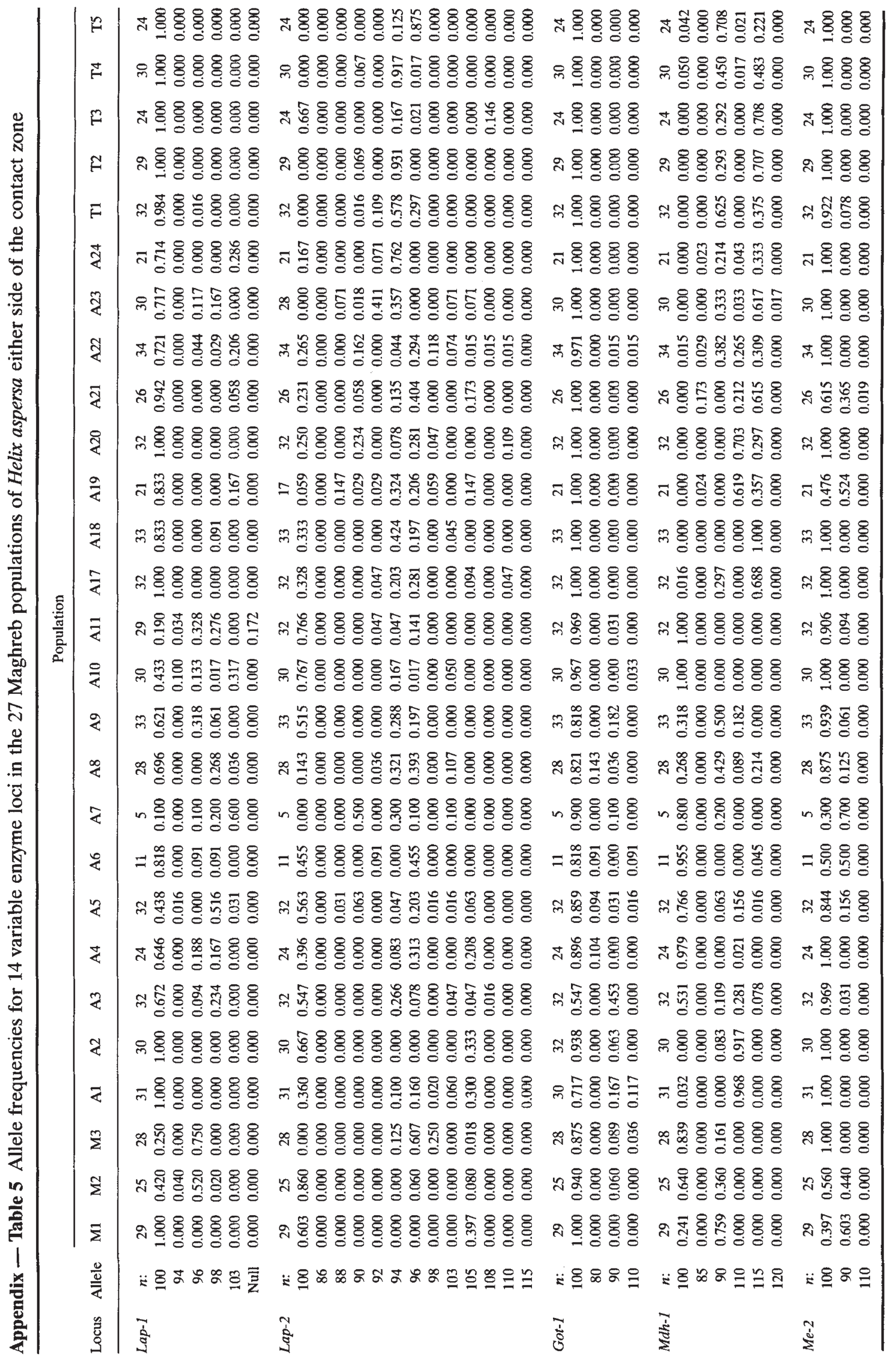




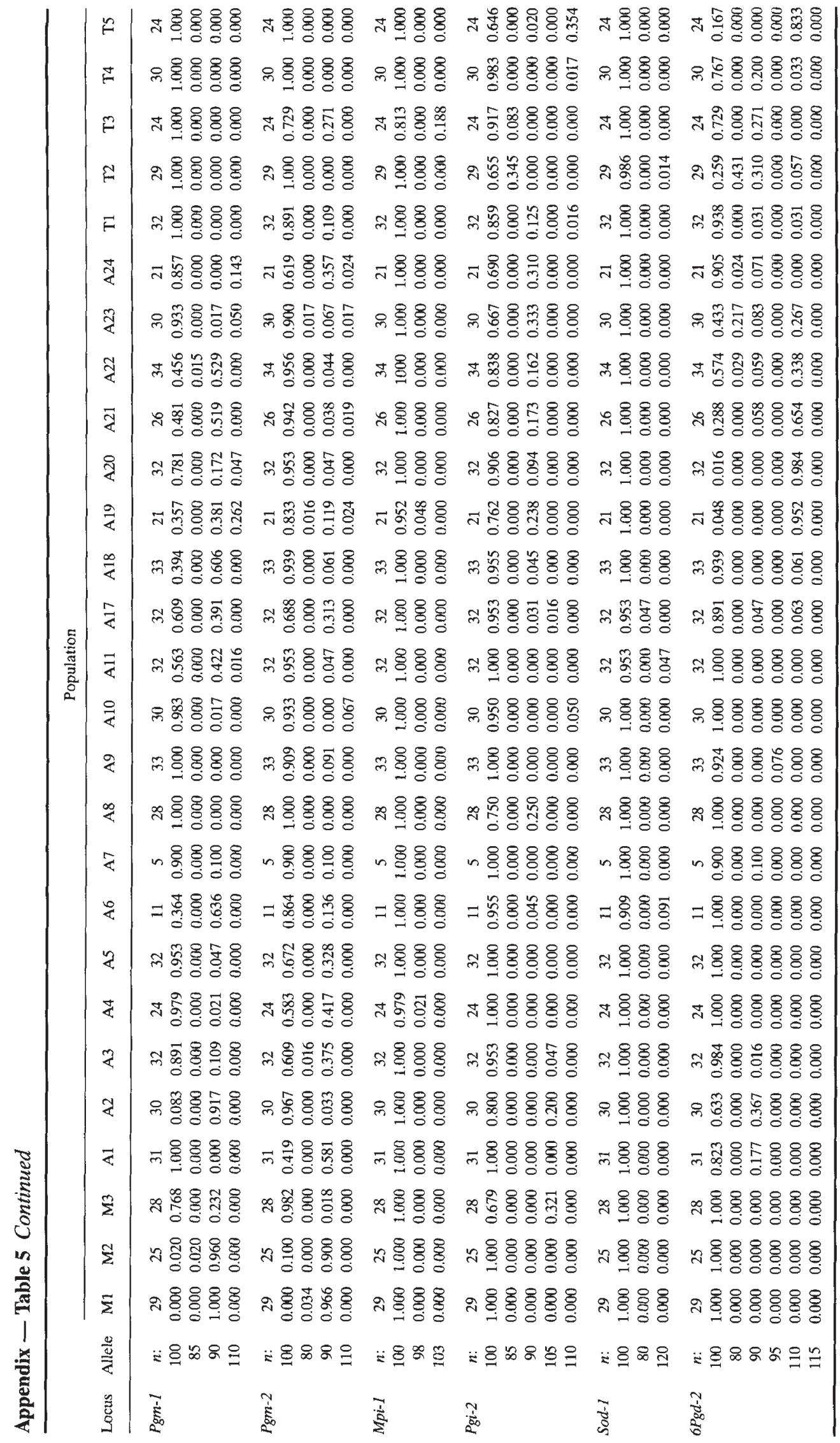




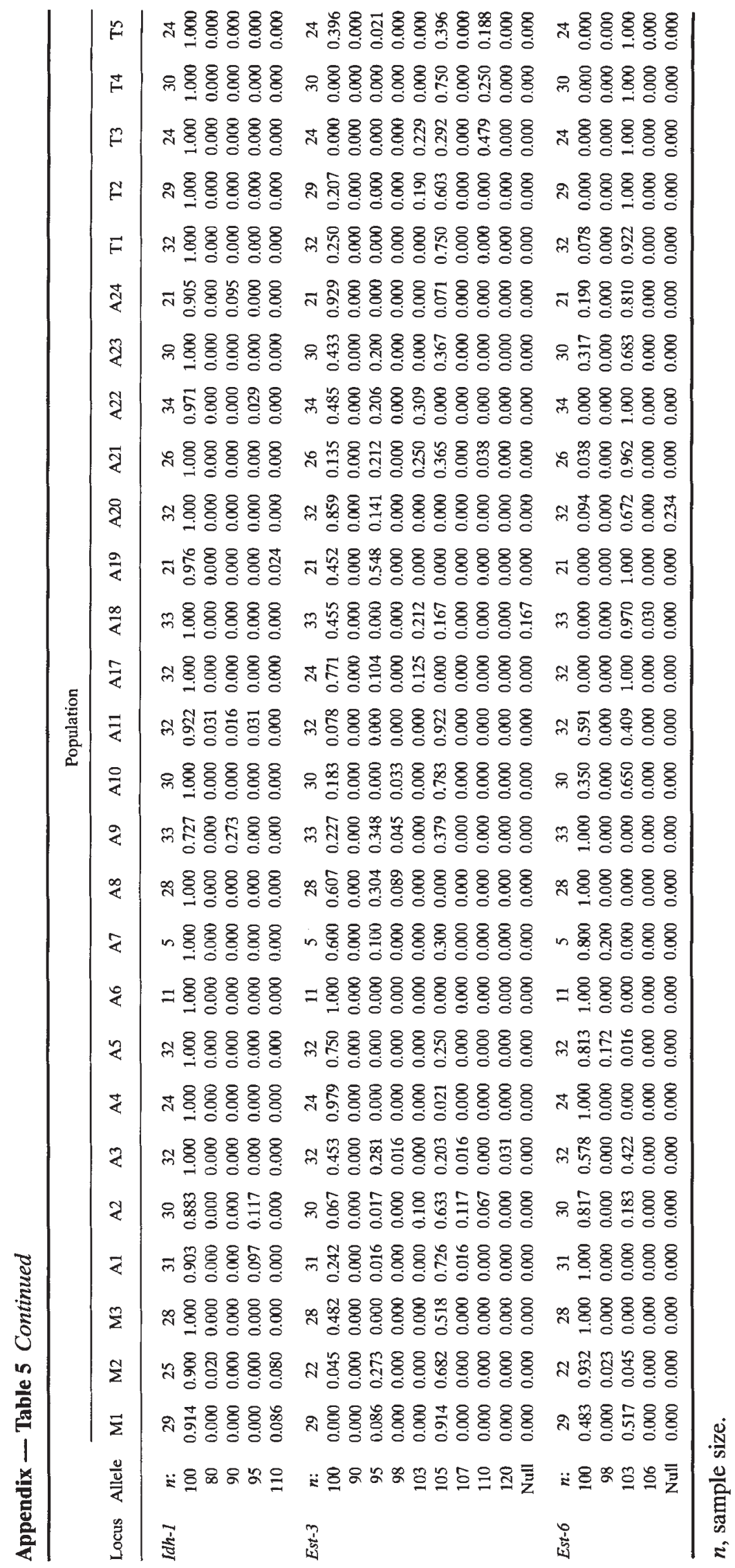

